\title{
Requirement for Daxx in mature T-cell proliferation and activation
}

\author{
J Leal-Sanchez ${ }^{1}$, A Couzinet ${ }^{1}$, A Rossin ${ }^{1}, \mathrm{~F}$ Abdel-Sater ${ }^{1}, \mathrm{~K}$ Chakrabandhu $^{1}$, C Luci ${ }^{2}$, F Anjuere ${ }^{2}$, E Stebe ${ }^{1}$, D Hancock ${ }^{3}$ and \\ A-O Hueber ${ }^{*}, 1$
}

The protein Daxx promotes Fas-mediated cell death through activation of apoptosis signal-regulating kinase 1, leading to the activation of the MAPKs JNK and p38. Owing to the in utero lethality of daxx-deficient mice, the in vivo role of Daxx has been so far difficult to analyze. We have generated transgenic mice expressing a dominant-negative form of Daxx (Daxx-DN) in the T-cell lineage. We show that Daxx is recruited to the Fas receptor upon FasL engagement and that Daxx-DN expression protects activated T cells from Fas-induced cell death, by preventing the death-inducing signal complex to be properly formed. Normal lymphocyte development and homeostasis are nevertheless observed. Interestingly, we report that both in vitro and in vivo stimulation of Daxx-DN T-lymphocytes leads to increased proliferative T-cell responses. This increased proliferation is associated with a marked increase in tyrosine phosphorylation of LAT and ZAP70 as Daxx-DN favor their recruitment to the T-cell receptor (TCR) complex. These findings identify Daxx as a critical regulator of T-lymphocyte homeostasis by decreasing TCRinduced cell proliferation and by promoting Fas-mediated cell death.

Cell Death and Differentiation (2007) 14, 795-806. doi:10.1038/sj.cdd.4402056; published online 3 November 2006

The tumor necrosis factor receptor (TNFR) superfamily members are cell-surface cytokine receptors controlling cell fate decisions, for example, proliferation, differentiation and cell death. ${ }^{1}$ A prototype of the death receptor TNFR subfamily is Fas (CD95; APO-1). Fas-induced cell death has a critical role in both naturally and pathologically occurring cell death in several contexts including the development and the homeostasis of the immune and central nervous systems. ${ }^{2}$

Upon engagement by its ligand (FasL), Fas rapidly recruits the adaptor molecule FADD to the membrane via a homologous death domain (DD) interaction. FADD then binds the caspase 8 proenzyme through an interaction with a homologous death effector domain (DED), leading to the formation of the death-inducing signal complex (DISC) ${ }^{2}$ and proteolytic auto-activation of caspase 8 . Mature caspase 8 then activates other caspases, which are presumed to execute the apoptotic dismantling of the cell. Among the substrates for caspase 8 is Bid, a proapoptotic member of the Bcl-2 family. Caspase 8-cleaved Bid targets mitochondria and induces cytochrome $c$ release, thereby amplifying the death signal. ${ }^{3}$

In addition to this classical FADD-dependent Fas pathway, in some transformed cells, a FADD-independent Daxx signalling pathway has been reported necessary for Fasmediated cell death. ${ }^{4,5}$ Daxx, an adaptor protein without a conventional DD, was first identified in a yeast two-hybrid screen through its ability to bind the DD of Fas via its Cterminal region, ${ }^{4}$ independently of the binding of FADD to Fas. ${ }^{6}$ In many cell lines, Daxx overexpression leads to an enhanced Fas-mediated apoptosis through a pathway sensitive to inhibition by $\mathrm{Bcl}-2,{ }^{4,7-9}$ although its role have been challenged by Villunger et al. ${ }^{10}$

Interestingly, Daxx was also found localized in the nucleus, where it can associate directly with different DNA-binding transcription factors and functions as a transcriptional repressor. ${ }^{11}$ It is notably recruited to the promyelocytic leukemia (PML) oncogenic domains interacting with the SUMO-1-modified PML. More recently, it was found that Daxx can modulate the function of $\mathrm{mdm} 2$ regulating therefore DNA damage-induced p53 activation. ${ }^{12,13}$

The importance of Fas and FasL in lymphocyte homeostasis and peripheral tolerance is revealed by the identification of mutations in their genes in both mice and humans where both lymphoproliferation and autoimmunity are observed. ${ }^{14}$ Mice deficient in FADD, caspase 8 or FLIP (through either a germline deficiency or an overexpression of a dominant-negative form (DN) form) do not develop such pathological features, but present an unexpected defect in T-cell activation. ${ }^{15-18}$

As we recently demonstrated that Daxx and FADD pathways are both necessary for Fas-induced motoneuron death and operate in parallel, ${ }^{19}$ we wished to investigate the physiological role of Daxx in T-cell homeostasis in vivo. Since targeted disruption of the daxx gene results in early embryonic lethality, ${ }^{20}$ we chose to generate transgenic mice expressing, under the control of the lck promoter, a DN form of the mouse Daxx (Daxx-DN) protein. We show here that Daxx-DN transgenic peripheral $\mathrm{T}$ cells are not only resistant to

\footnotetext{
${ }^{1}$ Equipe Labellisée par La Ligue Nationale Centre le Cancer Institute of Signalling, Developmental Biology and Cancer Research, CNRS UMR 6543, Nice, France; ${ }^{2}$ Faculté de Médecine Pasteur, INSERM U721, Nice, France and ${ }^{3}$ Lincoln's Inn Fields Laboratories, London Research Institute, Cancer Research UK, London, UK ${ }^{*}$ Corresponding author: A-O Hueber, Institute of Signalling, Developmental Biology and Cancer Research, CNRS UMR 6543, Centre A. Lacassagne, 33, Avenue de Valombrose, 06189 Nice, France. Tel: +00 33 492031241; Fax: +00 33 492031245; E-mail: hueber@unice.fr

Keywords: TCR; lymphocyte; proliferation; Daxx; signalling

Abbreviations: NLC, normal littermate control; CFSE, carboxyfluorescein diacetate succinimidyl ester; DN, dominant negative; TCR, T-cell receptor

Received 21.4.06; revised 08.9.06; accepted 19.9.06; Edited by JP Medema; published online 03.11.06
} 
Fas-mediated cell death but also more sensitive to T-cell receptor (TCR)-triggered proliferation in vivo.

\section{Results}

Generation of Ick Daxx-DN transgenic (Daxx-DN Tg) mice. To inhibit the function of Daxx in vivo, we generated independent lines of transgenic mice expressing a mouse Daxx-DN (amino acids 628-739) fused to a FLAG tag under transcriptional control of the lck proximal promoter (Figure 1a). This mutant contains only the Fas binding domain of Daxx, which mediates interaction of Daxx to the DD of Fas but lacks the apoptosis activation domain of Daxx (501-625), which is sufficient for the apoptotic activity of $\operatorname{Daxx}^{4}$ (Figure 1a). Out of the four transgenic lines produced, one line, expressing the highest transgenic Daxx-DN, was chosen for further analysis.

Immunoblot revealed the presence of proteins corresponding to the expressed transgene in lysates from mature splenic T cells of Daxx-DN Tg mice (Figure 1b). This expression was confirmed by staining of the transgene in permeabilized cells and found equivalent in peripheral CD4 and CD8 T cells (Figure 1c).

Daxx-DN expression interferes with neither thymocyte development nor peripheral T-cell homeostasis. The Daxx-DN Tg mice appear healthy with normal cell counts for thymus, spleen and lymph nodes at 4-24 weeks of age (Supplementary Table 1). To identify a potential role for Daxx in thymocyte development or peripheral T-cell homeostasis, major thymocyte or mature T-cell subpopulations from Daxx$D N \mathrm{Tg}$ mice and normal littermates control (NLC) mice were analyzed by flow cytometry for expression of different surface marker antigens. A normal representation populations and expression were found in thymus (data not shown) and in spleen or lymph nodes (Supplementary Figure 1), suggesting that Daxx-DN expression does not have an apparent effect neither on thymocyte development nor on T-cell homeostasis.

Activated $\mathrm{T}$ cells from Daxx-DN Tg mice are protected against FasL-induced cell death. Primary $T$ cells become sensitive toward FasL-induced apoptosis 3-5 days after activation. $^{21}$ Consistent with these data, we found that resting $T$ cells were insensitive to killing by recombinant FasL, whereas activated $T$ cells from control mice were rapidly killed after incubation with recombinant FasL (Figure 2a). In contrast, T cells derived from Daxx-DN Tg mice were protected against FasL-induced cell death from day 3 following activation (Figures $3 a$ and $b$ ), whereas no difference of the level of Fas expression at the cell surface of NLC and Daxx-DN T cells could be detected (data not shown). The extent of inhibition found is similar to that found in the presence of the caspase inhibitor Z-VAD or the

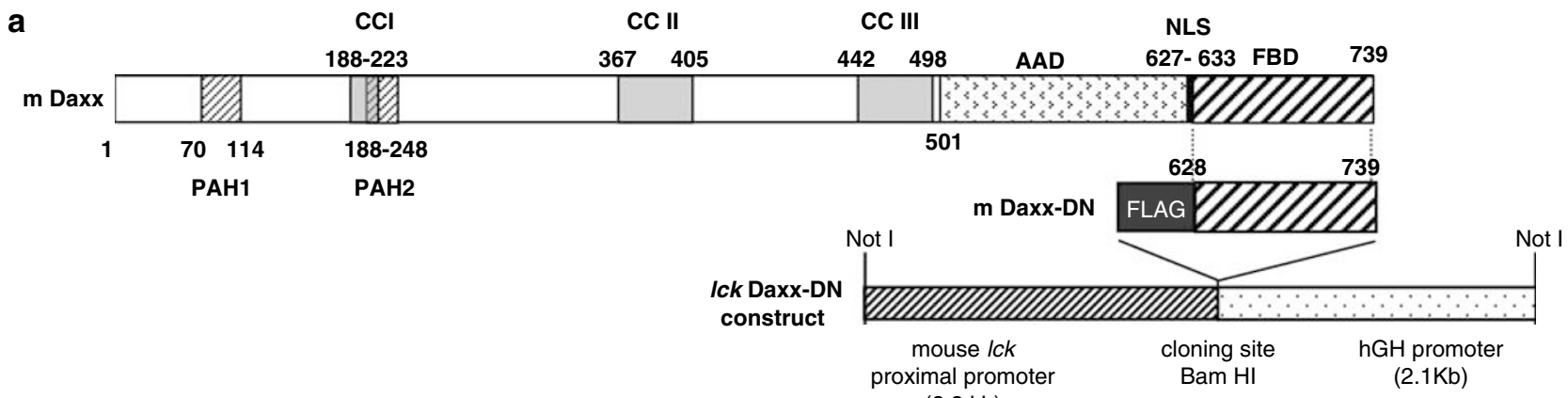

C

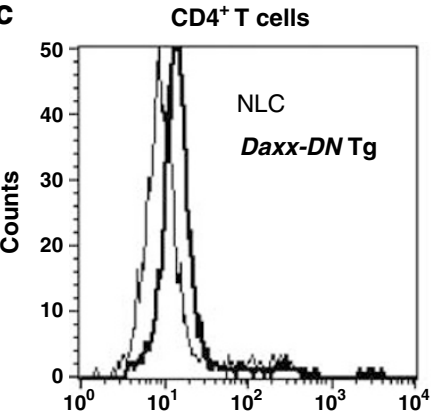

$(3.2 \mathrm{~kb})$

b

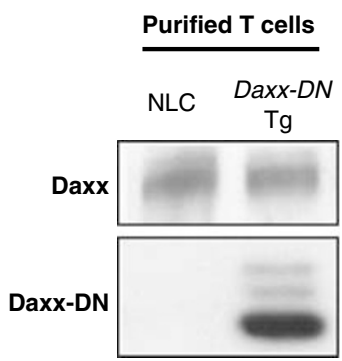

$\mathrm{CD}^{+} \mathrm{T}$ cells

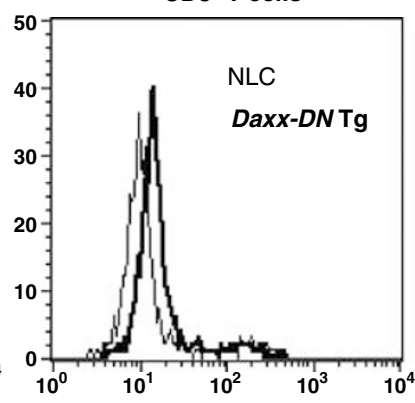

B cells

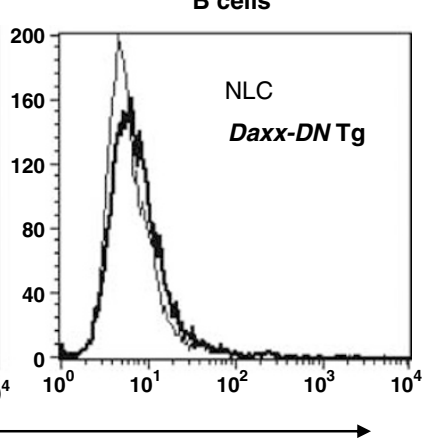

M5 Ab (anti-Flag)

Figure 1 Generation of Daxx-DN Tg mice and transgenic expression in T cells. (a) Schematic representation of the Ick Daxx-DN transgene: the mouse Daxx-DN cDNA encoding amino acids 628-739 of Daxx fused at its amino terminus to a FLAG epitope tag was cloned into the P1017 vector. PAH, paired amphipathic helix; CC, coiled coil; FBD, Fas binding domain. The numbers indicate amino-acid positions. (b and c) Expression of the Daxx-DN transgene in peripheral T cells from the Daxx-DN Tg mice. Western blot analysis of Daxx-DN transgene expression in purified T cells lysates from NLC and Daxx-DN Tg mice using a rabbit polyclonal antibody directed against the C-terminal region of Daxx (M112) (b). Flow cytometry analysis of Daxx-DN transgene expression using an anti-FLAG antibody (M5) on fixed and permeabilized B splenocytes and $\mathrm{CD}^{+}{ }^{+}$or $\mathrm{CD}^{+}{ }^{+}$lymphocytes from NLC (thin histogram) and Daxx-DN Tg (thick histogram) mice (c) 

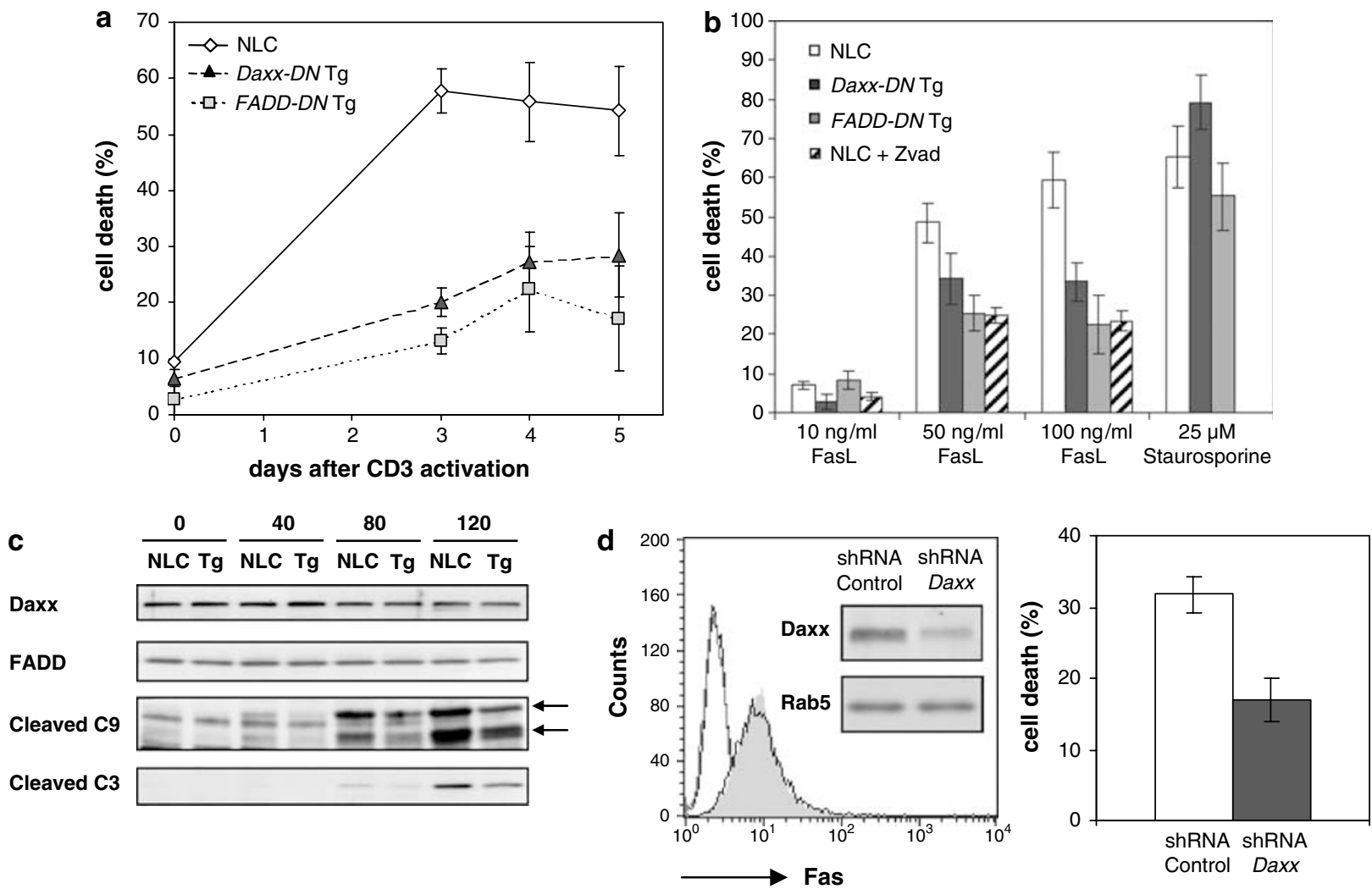

Figure 2 T cells from Daxx-DNTg mice are resistant to FasL-induced cell death. T lymphocytes isolated from spleen of 6- to 10-week-old NLC, Daxx-DN Tg or FADD-DN $\mathrm{Tg}$ mice were purified and stimulated with $50 \mathrm{U} / \mathrm{ml} \mathrm{IL-2} \mathrm{plus} \mathrm{coated} \mathrm{antibody} \mathrm{to} \mathrm{CD3} \mathrm{at} 1 \mu \mathrm{g} / \mathrm{ml}$ for 4 days (b and $\mathbf{c}$ ) or for indicated times (a). The cells were then collected and plated at $1 \times 10^{6} \mathrm{cells} / \mathrm{ml}$ for $4 \mathrm{~h}$ with $100 \mathrm{ng} / \mathrm{ml}$ FLAG-rhFASL plus $1 \mathrm{mg} / \mathrm{ml}$ anti-FLAG antibody (a and c), with titrated amounts of recombinant FasL plus $1 \mu \mathrm{g} / \mathrm{ml}$ anti-FLAG antibody (with or without Z-VAD, $10 \mu \mathrm{M}$ ) or with staurosporine $(25 \mu \mathrm{M})(\mathbf{b})$. (c) Western blot analysis of total lysates of purified T splenocytes, activated for 4 days with coated anti-CD3 $(1 \mu \mathrm{g} / \mathrm{ml})$ plus IL-2 $(50 \mathrm{U} / \mathrm{ml})$ and then treated or not with $100 \mathrm{ng} / \mathrm{ml}$ FLAG-rhFASL plus $1 \mu \mathrm{g} / \mathrm{ml}$ anti-FLAG antibody for the indicated time. Blots were probed with anticaspase 9, anti-caspase 3, anti-FADD and anti-Daxx antibodies. Results shown are from a representative experiment of four. (d) Inhibition of Fas-mediated cell death in Daxx shRNA expressing L12.10.Fas T cells. Cells $\left(0.5 \times 10^{6} / \mathrm{ml}\right)$ stably expressing short hairpin Daxx siRNA (shRNA Daxx) or control siRNA (shRNA control) were incubated for $4 \mathrm{~h}$ with $25 \mathrm{ng} / \mathrm{ml}$ FLAG-rhFASL plus $1 \mu \mathrm{g} / \mathrm{ml}$ anti-FLAG antibody. An equivalent Fas expression level on both cells and the knockdown of Daxx expression were analyzed by flow cytometry and Western blot analysis, respectively

expression of FADD-DN (Figure 2b). Importantly, the death receptor-independent cell death induced by staurosporine was unaffected by Daxx-DN expression (Figure 2b). Consistent with the delayed cell death, the cleaved fragments of caspases 3 and 9 were barely detectable after Fas triggering when Daxx-DN was expressed (Figure 2c). To check whether the effect of Daxx-DN lied upstream of the caspase 8 activation, we immunoprecipitated either the unstimulated or the stimulated Fas receptor and compared the efficiency of the DISC formation in NLC and Tg T cells. As seen in Figure $3 b$, both FADD and caspase 8 were significantly less recruited to the Fas receptor in Daxx-DNTg $T$ cells. Interestingly, we can show that the Daxx protein is recruited within the DISC (Figure $3 \mathrm{a}$ ). These results are consistent with our immunofluorescence studies showing that the endogenous Daxx is redistributed from the nucleus to the cytoplasm upon Fas stimulation (Supplementary Figure 2). Not only the recruitment of Daxx to Fas was significantly reduced in Daxx-DN T cells but also the presence of the Daxx-DN form, already detectable in the Fas immunoprecipitates in unstimulated conditions, was even more pronounced upon Fas engagement (Figure 3b). Thus, we concluded that the Daxx-DN expression prevents the DISC to be properly formed by preventing the recruitment of the endogenous Daxx protein to the DISC following Fas stimulation.

Fas-mediated cell death assays and Fas immunoprecipitation experiments were also performed on L12.10.Fas T cells stably silenced for the Daxx expression (Daxx short hairpin RNA (shRNA)). Daxx was also recruited to the DISC in this cell line, and daxx knockdown resulted in an inhibition of Fasmediated cell death (Figure 2d and Supplementary Figure 3), owing to the inhibition of the DISC formation (Figure 3c).

In vitro activation-induced cell death (AICD) but not in vivo AICD is inhibited in Daxx-DN Tg T cells. We next examined the sensitivity of mature Daxx-DN Tg T cells to in vitro AICD. We found that preactivated splenic $T$ cells from NLC mice were more sensitive to anti-CD3-induced cell death than Daxx-DN preactivated cells (Figure 4a).

Daxx-DN Tg mice did not develop lymphadenopathy or age-dependent autoimmune disease typical for the Iprand gld 
a

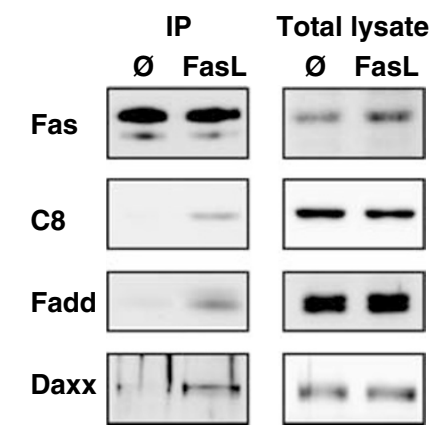

b

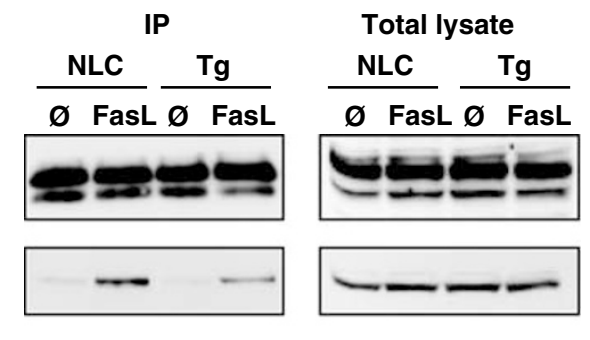

C8

Fas

Fadd

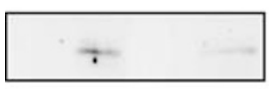

Daxx
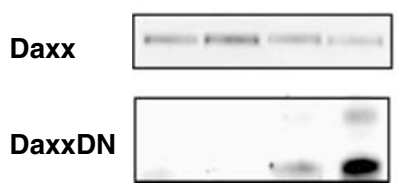

c

\begin{tabular}{|c|c|c|c|}
\hline \multicolumn{4}{|c|}{ IP } \\
\hline & $\begin{array}{l}\text { RNA } \\
\text { ntrol }\end{array}$ & & $\begin{array}{l}\text { RNA } \\
\text { axx }\end{array}$ \\
\hline$\varnothing$ & FasL & $\varnothing$ & FasL \\
\hline
\end{tabular}

Fas

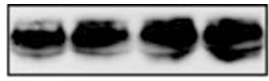

Fadd

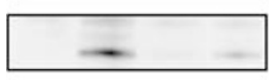

Daxx

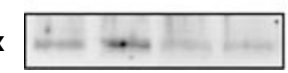

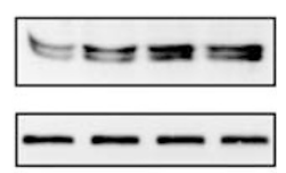

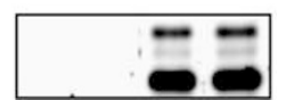

Total Lysate

shRNA ShRNA

Control Daxx

Ø FasL Ø FasL
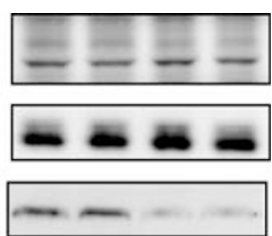

Figure 3 Daxx is recruited to the DISC and Daxx-DN or Daxx knockdown inhibits DISC formation. (a) CD3-activated T cells $\left(5 \times 10^{7}\right)$ isolated from wild-type mice were stimulated with $200 \mathrm{ng} / \mathrm{ml}$ FLAG-rhFasL plus $2 \mu \mathrm{g} / \mathrm{ml}$ M2 for $3 \mathrm{~min}$ or left unstimulated at $37^{\circ} \mathrm{C}$. Fas was immunoprecipitated with biotinylated JO2 anti-Fas antibody $(2 \mu \mathrm{g})$ coupled to streptavidin-agarose beads at $4^{\circ} \mathrm{C}$, for $4 \mathrm{~h}$. The immunoblotting was performed with the indicated antibodies. (b) CD3-activated T cells $\left(5 \times 10^{7}\right)$ isolated from NLC or Daxx-DN (Tg) mice and stimulated with $200 \mathrm{ng} / \mathrm{ml} \mathrm{FLAG-rhFasL} \mathrm{plus} 2 \mu \mathrm{g} / \mathrm{ml}$ M2 for $10 \mathrm{~min}$ or left unstimulated. Then Fas was immunoprecipitated as described in (a). (c) Fas immunoprecipitation was performed on L12.10 cells stably expressing short hairpin Daxx siRNA (shRNA Daxx) or control siRNA (shRNA control) after stimulation with $100 \mathrm{ng} / \mathrm{ml}$ FLAGrhFasL plus $2 \mu \mathrm{g} / \mathrm{ml} \mathrm{M} 2$ for $3 \mathrm{~min}$

mice defective in Fas/FasL signalling, indicating that, in contrast with our in vitro studies, AICD may not be impaired by Daxx-DN overexpression in vivo. We therefore examined whether in vivo AICD was affected by Daxx-DN transgene expression. We first analyzed the deletion of the $\mathrm{V} \beta 3 \mathrm{~T}$ cell population, through the presence of endogenous superantigen mtv6 in BALB/c mice by breeding BALB/c mice to

Daxx-DN Tg mice (in a C57BL/6 background). The deletion of the autoreactive $\mathrm{V} \beta 3 \mathrm{~T}$ cells in C57BL/6 $\times$ BALB/c mice was not rescued by the presence of $D a x x-D N$ transgene indicating that the Daxx-DN transgene did not prevent in vivo AICD (Figure $4 b$ ). We confirmed this result by examining the response of activated $\mathrm{T}$ cells from Daxx-DN Tg mice after injection with the superantigen Staphylococcal enterotoxin B (SEB). We analyzed the ability of activated $T$ cells to be eliminated by comparing the percentage of SEB-reactive $\mathrm{V} \beta 8^{+} \mathrm{T}$ cells in the spleen and the lymph nodes of NLC and Daxx-DN mice between 3 and 8 days after injection. We found that expression of Daxx-DN did not obviously modify the clearance of SEB-activated T cells in vivo (Figure 4c).

Increased activation-induced proliferation of Daxx-DN $\mathrm{Tg}$ peripheral $\mathrm{T}$ cells. During the course of in vitro AICD experiments (Figure $4 \mathrm{a}$ ), we observed that the Daxx-DN T cells proliferated more readily than their NLC counterparts upon CD3 stimulation. Cell cycle distribution of 4-day antiCD3-activated T cells revealed that $20 \%$ of living NLC T cells are in $\mathrm{S}+\mathrm{G} 2 / \mathrm{M}$ phases compared to $49 \%$ of living Daxx-DN $\mathrm{T}$ cells and $4 \%$ of living FADD-DN T cells (Figure $5 \mathrm{a}$ ). Therefore, whereas FADD-DN effectively blocked the proliferative response of $\mathrm{T}$ cells induced by anti-CD3 as previously reported, ${ }^{22-24}$ Daxx-DN has an inverse effect by increasing T-cell proliferation. This effect could be clearly seen from day 3 of activation with peripheral $T$ cells (Figure $5 b$ ). To better investigate the effect of the Daxx-DN transgene on proliferative response, we analyzed T-cell proliferation through in vitro ${ }^{3}[\mathrm{H}]$ thymidine incorporation assays. Activation-induced proliferation of $\operatorname{Daxx}-D N \mathrm{~T}$ cells was increased when compared with NLC $T$ cells. Interestingly, this hyperproliferative behavior was even more pronounced when lower concentrations of anti-CD3 were used and cannot be observed after a PMA/ionomycin stimulation, indicating that the defect was probably close to the proximal events of the TCR signalling (Figure 5c).

To ensure that the increase in activation-induced expansion observed with Daxx-DN T cells was not simply the result of increased cell survival but was really a defect in cell cycling, we analyzed proliferation through carboxyfluorescein diacetate succinimidyl ester (CFSE) labeling. The histograms obtained revealed the distribution of sequential cell divisions (Figure $5 d$ ). These data clearly confirmed that $T$ cells from Daxx-DN mice proliferated more than those from NLC, whereas $T$ cells from $F A D D-D N$ mice proliferated poorly (data not shown).

Aberrant expression of cell cycle proteins in Daxx-DN Tg T cells upon CD3 stimulation. To better understand how and at which level overexpression of Daxx-DN affects the regulation of cell cycle in T cells, we studied by immunoblot analyses the expression of a panel of cell cycle proteins known to be regulated in T cells upon CD3 stimulation. Total proteins were extracted from purified T cells, and the levels of different cyclins, cyclins-dependant kinases (CDKs) or CDK inhibitors (CDKls) (Figure 6) were studied. Both NLC and Daxx-DN resting $T$ cells (G0 stage of the cell cycle) express moderate or null basal levels of cyclins A, E, D3 and CDKs 2, 4, 6. The CDKls p27, p15, p16 and cyclin D1 are all readily 

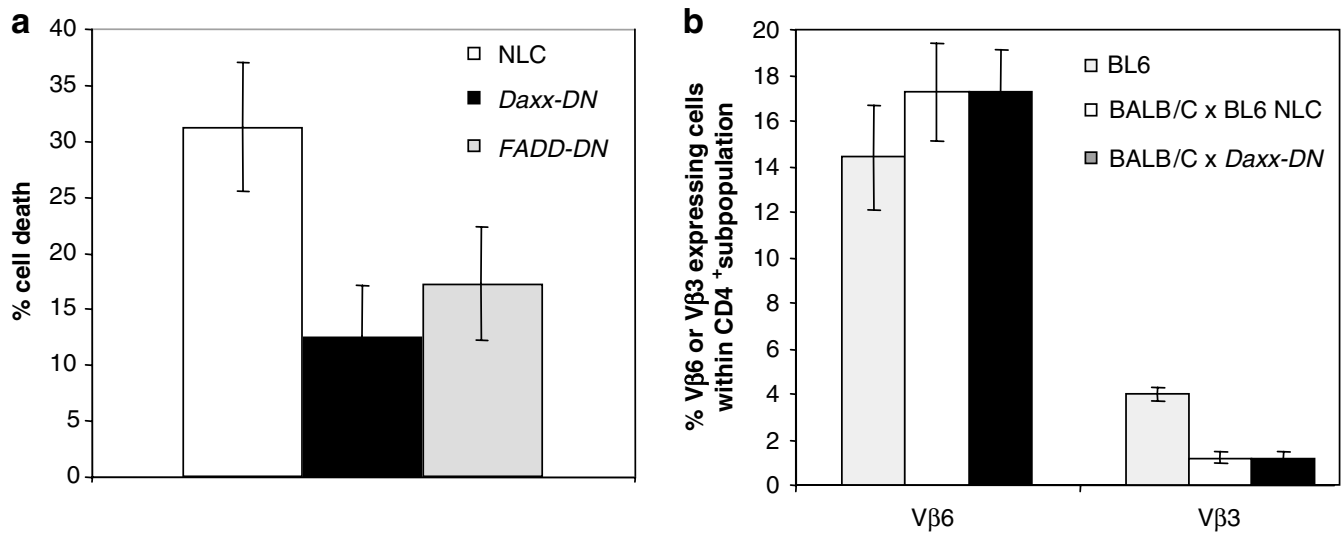

C

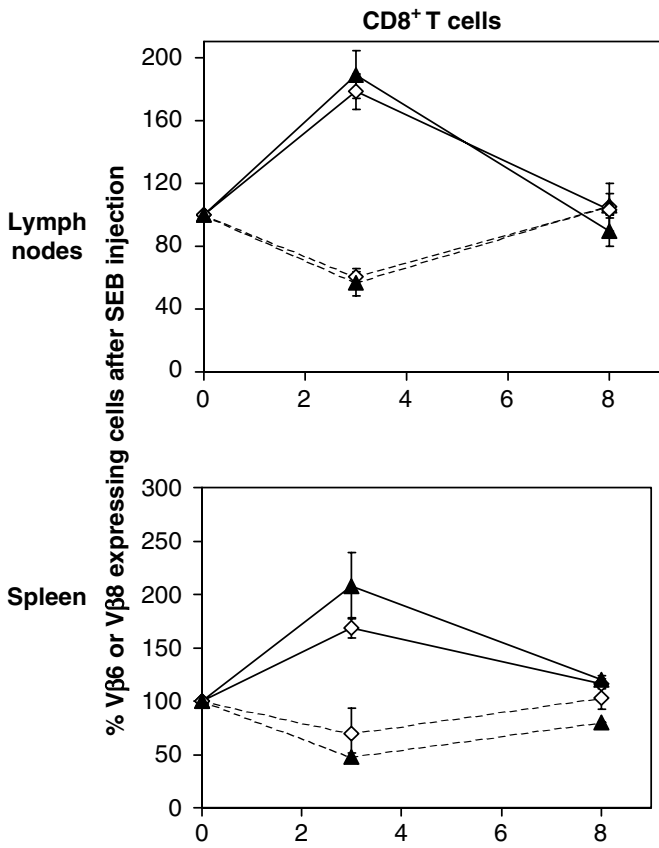

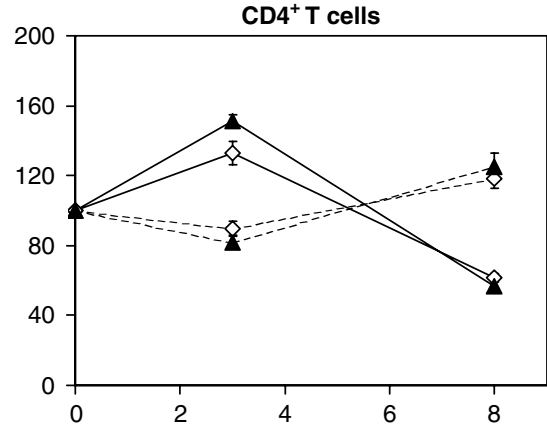
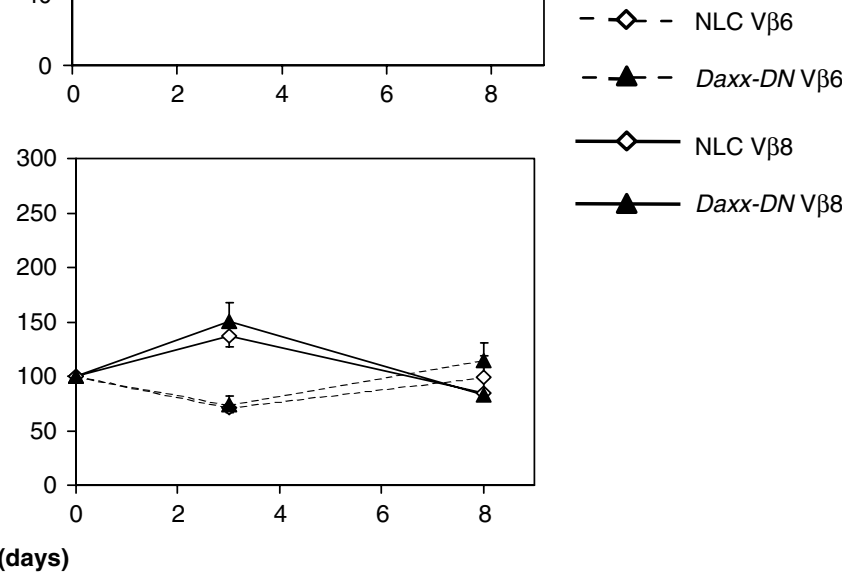

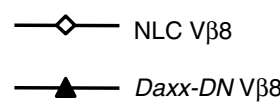

Daxx-DN V 1 -

Figure 4 AICD in vitro and in vivo in Daxx-DN Tg mice. (a) Purified spleen T cells from NLC, FADD-DN or Daxx-DN Tg mice were stimulated with coated anti-CD3 MAb $(1 \mu \mathrm{g} / \mathrm{ml})$ and IL-2 $(50 \mathrm{U} / \mathrm{ml})$ for 4 days. Cells were washed and put back into culture in the presence of IL-2 $(50 \mathrm{U} / \mathrm{ml})$ only for an extra 2 additional days. The cells were then collected, and live cells enriched onto a Ficoll gradient. The preactivated T cells were restimulated with plate-bound CD3 MAb $(1 \mu \mathrm{g} / \mathrm{ml})$ during $24 \mathrm{~h}$. Cell viability was determined by PI staining on ethanol-fixed cells and cytometry analysis. Mean standard deviations of triplicate determinations are shown. (b) mtv6-induced T-cell deletion in vivo. NLC or Daxx-DN Tg mice onto a BALB/c background express the endogenous superantigen mtv6. Deletion of V $\beta 3$ TCR-expressing CD4 ${ }^{+} \mathrm{T}$ cells was monitored by staining total splenocytes of DBA/2 mice with anti-V $\beta 3$-specific and anti-CD4 antibodies followed by cytometry analysis. V $\beta 6 \mathrm{~T}$ cells are not deleted by the superantigen mtv6, and their constant percentage among $\mathrm{CD} 4{ }^{+} \mathrm{T}$ cells determined with an anti-V $\beta 6 /$ anti-CD4 staining served as an internal control for this experiment. The bar graphs represent the mean percentage of $\mathrm{CD}_{4}{ }^{+} \mathrm{T}$ cells expressing $\mathrm{V} \beta 3$, or $\mathrm{V} \beta 6$ in spleen from C57BL/6, C57BL/6/Daxx-DN Tg mice backcrossed onto BALB/c and C57BL/6/NLC mice backcrossed onto BALB/c. Data values are the mean \pm S.D.s. (c) SEB-induced V $\beta 8^{+}$T cells deletion in vivo. SEB (100 $\mu \mathrm{g} /$ animal) was injected i.v. into NLC and Daxx-DN Tg mice, and T cells from both spleen and lymph nodes were analyzed 3 or 8 days post-injection. T cells with a V $\beta 6$ TCR $\beta$ chain are not responsive toward SEB superantigen and their constant percentage among peripheral $T$ cells before and after SEB injection served as a control for this experiment. Three mice were analyzed at each point. Data values are the mean \pm S.D.S

detectable whereas the CDKIs p21 and p19 expression is undetectable (Figure 6). As expected, CD3 stimulation in NLC $T$ cells leads to an induction of several key cyclins (cyclins A, E, D3) and CDKs (Cdk2, Cdk4, Cdk6), a decreased expression of the CDKIs p27, p15, p16, and a strong induction of CDKIs p21 and p19. Among all the cell cycle proteins examined, the induction of expression of the cyclins A, E, D3 and the CDKI p21 upon CD3 cross-linking was noticeably reduced in Daxx-DN T cells. The decreased expression of p21, a major pleiotropic inhibitor of several key CDKs, appears consistent with the increased proliferative status of the Daxx-DN T cells. In accordance with this observation, as the expression of $\mathrm{p} 21$ is regulated, in part, by the tumor suppressor gene p53, we found a dramatic 
a
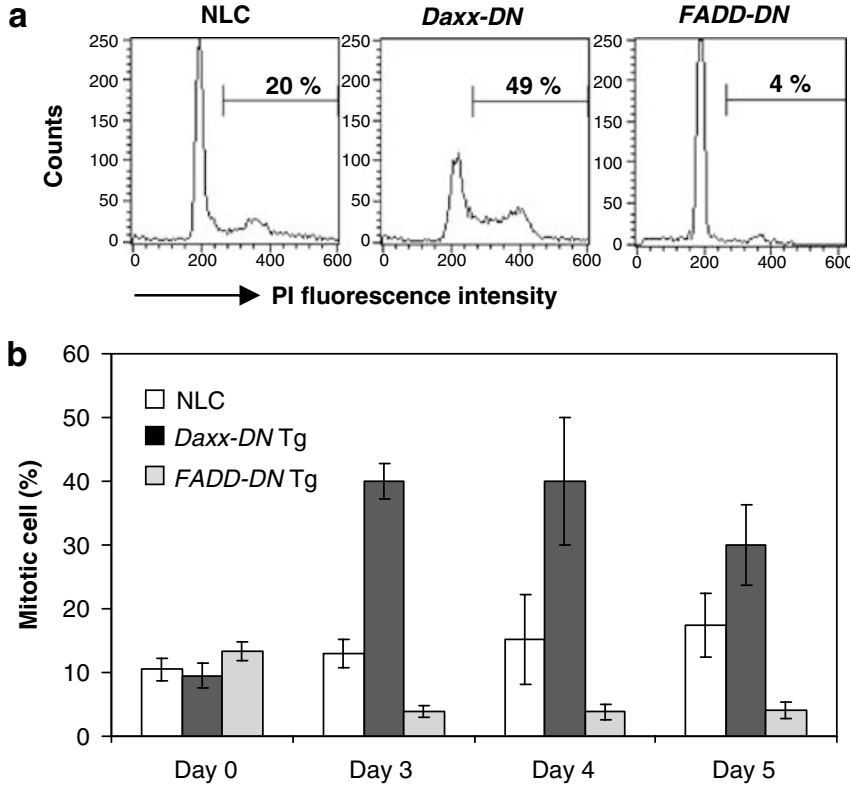

C

$\square$ NLC

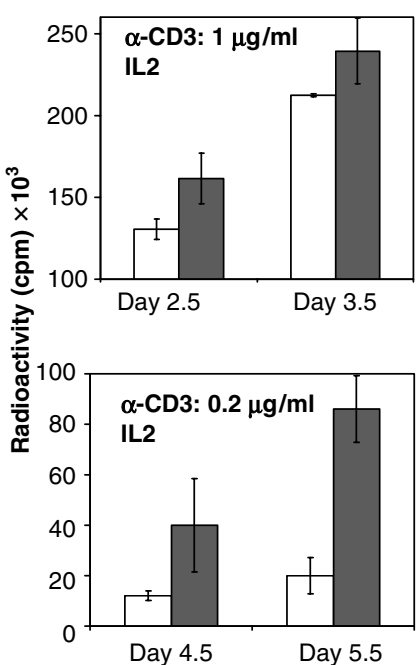

$\operatorname{Daxx}-D N \operatorname{tg}$
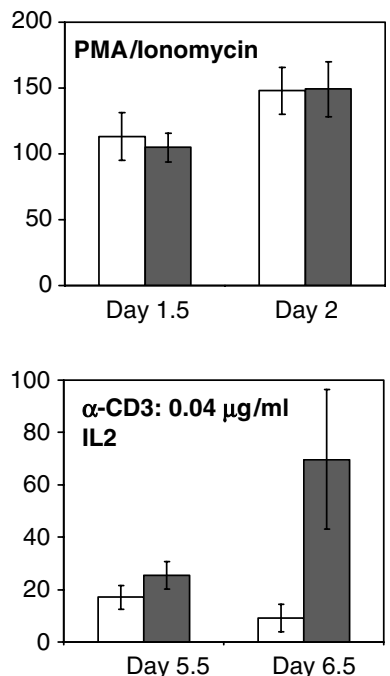

d

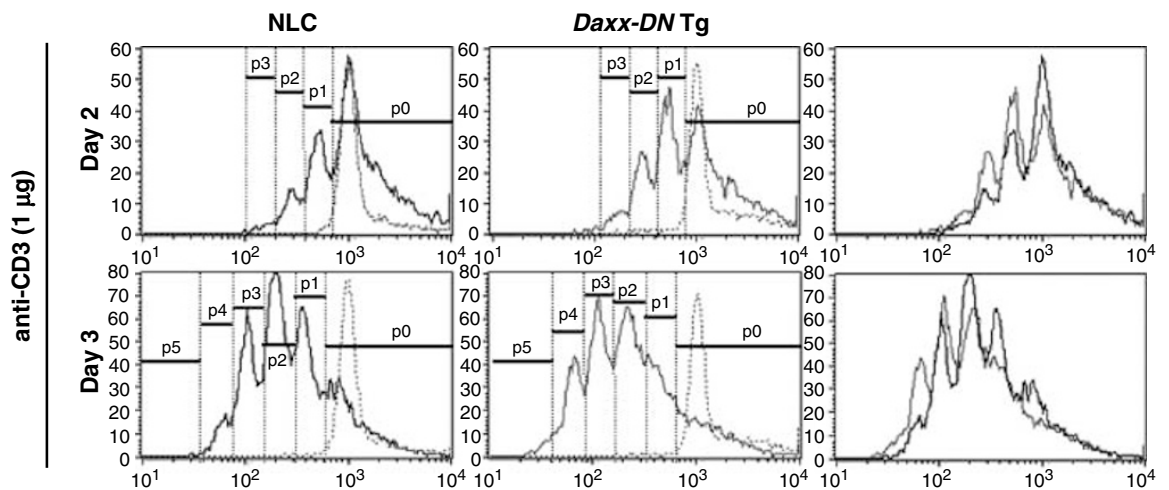

\begin{tabular}{ccc} 
& NLC & Daxx-DN \\
\hline P0 & 66.5 & 51.7 \\
P1 & 22.4 & 28.2 \\
P2 & 8.7 & 15.4 \\
P3 & 2.4 & 4.7 \\
\hline
\end{tabular}

\begin{tabular}{lcc}
\hline P0 & 21 & 16.6 \\
P1 & 23.6 & 16.9 \\
P2 & 31.9 & 28.3 \\
P3 & 18.6 & 22.9 \\
P4 & 4.5 & 12.6 \\
P5 & 0.5 & 2.6 \\
\hline
\end{tabular}

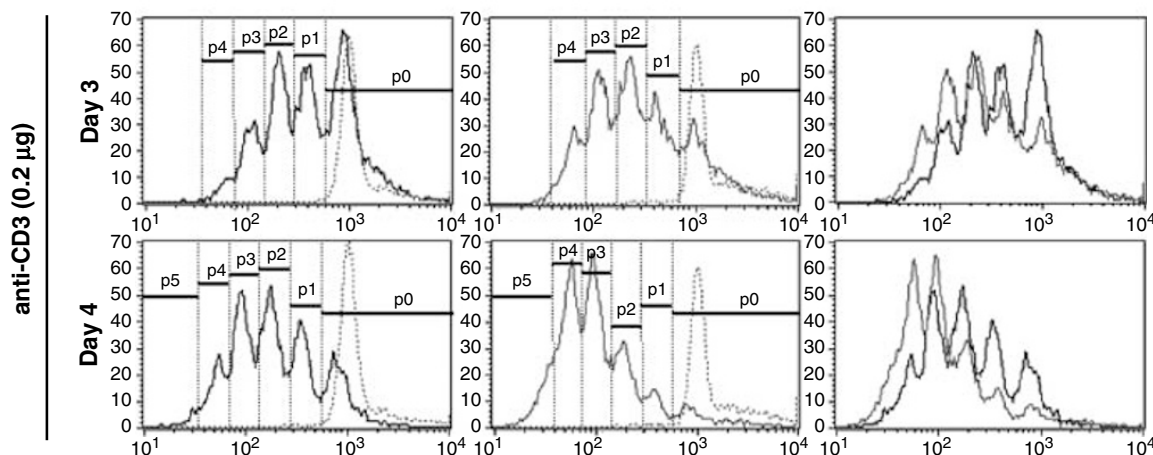

\begin{tabular}{lcc}
\hline P0 & 38.1 & 22 \\
P1 & 24 & 18.3 \\
P2 & 22.6 & 27.5 \\
P3 & 11.9 & 21.9 \\
P4 & 3.4 & 10.3 \\
\hline & & \\
\hline$P 0$ & 16.9 & 7.5 \\
P1 & 18.9 & 6.4 \\
P2 & 27.5 & 17.1 \\
P3 & 23.5 & 30.9 \\
P4 & 11.9 & 32.5 \\
P5 & 1.4 & 5.5 \\
\hline
\end{tabular}

Figure 5 Enhanced in vitro and in vivo proliferative responses in Daxx-DN Tg mice. (a) Purified spleen T cells from Daxx-DN Tg mice and NLC were activated with platebound anti-CD3 $(1 \mu \mathrm{g} / \mathrm{ml})$ and IL-2 $(50 \mathrm{U} / \mathrm{ml})$ for 4 days. The cells were collected, fixed with ethanol before the PI staining. The \% of living cells in S $+\mathrm{G} 2 / \mathrm{M}$ phases of the cell cycle was determined by flow cytometry analysis and is representative of at least five independent experiments. (b) The same experiment as in (a) was performed except that the cells were activated for 3,4 or 5 days. The bar graphs represent the mean percentage of living $T$ cells in $S+G 2 / M$ phases of the cell cycle. Data values are the mean \pm S.D.s of at least five experiments. (c) Purified spleen T cells from Daxx-DN Tg mice and NLC were activated with anti-CD3 (0.04, 0.2 or $1 \mu \mathrm{g} / \mathrm{ml})$ and IL-2 (50 U/ml) for 4 days or with PMA $(2 \mathrm{ng} / \mathrm{ml})$ and ionomycin $(0.2 \mu \mathrm{g} / \mathrm{ml})$ for the indicated number of days, and ${ }^{3}[\mathrm{H}]$ thymidine $(1 \mu \mathrm{Ci} /$ well) was added during the last $16 \mathrm{~h}$ of culture. (d) Fluorescence analysis of the proliferation of CFSE-labelled T cells upon CD3 activation. NLC and Daxx-DN T cells were purified from spleen, labelled with CFSE, and incubated for the indicated time on anti-CD3-coated plates before harvesting and analyzing. Representative CFSE flow cytometric profiles from non-stimulated (dashed line) or from anti-CD3-activated (solid line) CD4 ${ }^{+} \mathrm{T}$ cells from NLC or Daxx-DN mice are shown. The last column of histograms displays an overlay. Numbers represent percentages of cells in each division category (PO to P5). Shown is the result of a representative experiment

difference in p53 expression between NLC and Daxx-DN T cells. The reasons for the reduced levels of the G1-related cyclins, E, A, and D3, in Daxx-DN cells remain uncertain.

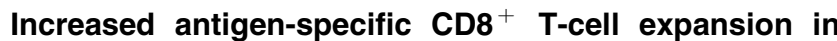
Daxx-DN Tg mice in vivo. We next examined the effect of the $D a x x-D N$ transgene on proliferation in an antigen-specific 

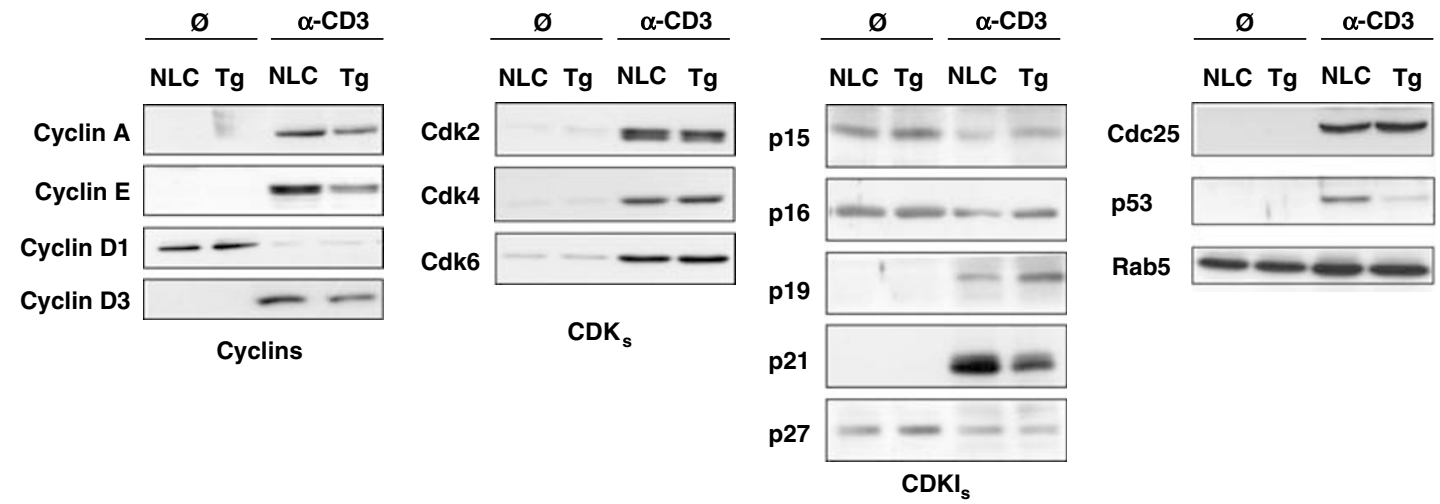

Figure 6 Cell cycle regulatory protein (cyclins, CDKs, CDKIs) expression profiles in NLC and Daxx-DN T cells following CD3 stimulation. Protein lysates were prepared from purified T cells untreated or treated with anti-CD3 antibodies for $48 \mathrm{~h}$. Western blot analysis was performed with the corresponding antibodies as described in Materials and Methods
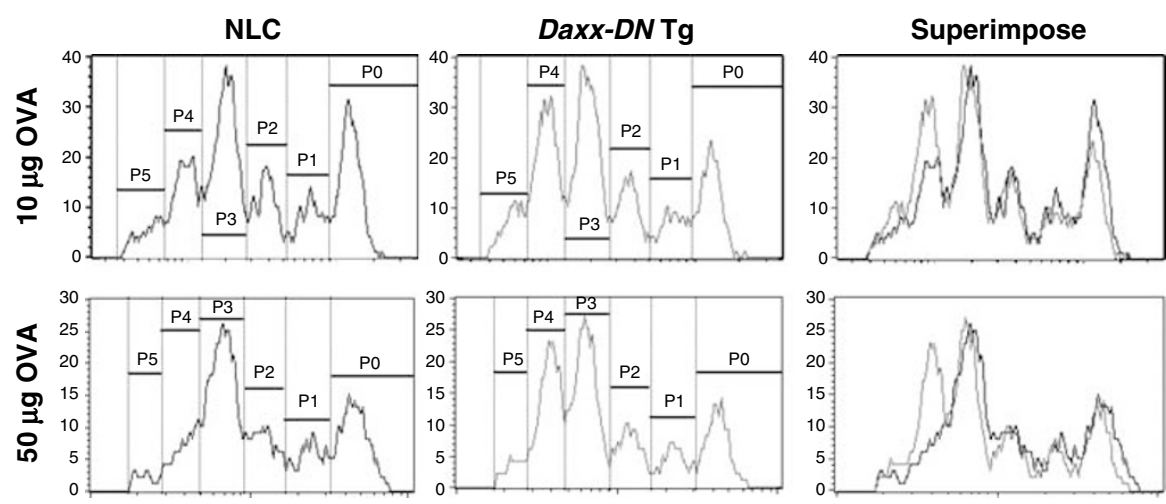

\begin{tabular}{|c|c|c}
\hline$\%$ & NLC & Daxx-DN \\
\hline P0 & 21.9 & 15.3 \\
P1 & 10.2 & 8.5 \\
P2 & 13.3 & 12.3 \\
P3 & 30.9 & 30.1 \\
P4 & 17 & 24 \\
P5 & 6.7 & 10.5 \\
\hline & & \\
\hline P0 & 21.5 & 15.1 \\
P1 & 10.7 & 8.4 \\
P2 & 16 & 12.8 \\
P3 & 37.5 & 32.6 \\
P4 & 12.5 & 27.1 \\
P5 & 2.75 & 4.77 \\
\hline
\end{tabular}

Figure 7 Enhanced in vivo proliferative responses in Daxx-DN Tg mice. Enhanced antigen-specific proliferative response of Daxx-DN T cells. Daxx-DN Tg mice were crossed with OT-1 mice that express an MHC class I-restricted transgenic TCR specific for an Ova protein. T cells from each group of mice (OT-1 TCR Tg and OT-1 TCR Tg/ Daxx-DN) were purified from spleen and CFSE labelled before being transferred into recipient mice. Mice were then immunized with OVA protein/CFA. Two days following immunization, in vivo proliferative response was determined by CFSE profile analysis within the TCR transgenic $\mathrm{CD} 8^{+} \mathrm{V} \alpha 2^{+} \mathrm{T}$-cell subset. Numbers represent percentages of cells in each division category (P0 to P5). Shown is the result of a representative experiment

model of T-cell proliferation in vivo. To this end, we crossed the Daxx-DN Tg mice to the TCR Tg OTI mice expressing a transgenic TCR, $\mathrm{V} \alpha 2$, specific for the SIINFEKL peptide of OVA in the context of MHC class I, $\mathrm{H} 2-\mathrm{Kb}^{25}$

To compare the proliferative ability of the TCR transgenic T cells (originated from OT1/wt or OT1/Daxx-DN) in the absence or the presence of Daxx-DN, purified and CFSElabelled $\mathrm{T}$ splenocytes were transferred into congenic host mice followed by subcutaneous immunization with OVA and CFA adjuvant. Two days later draining lymph nodes were excised and T-cell proliferative responses were examined. Following an immunization with $10 \mu \mathrm{g}$ OVA, 34.5\% of OTI/ Daxx-DN T cells had already undergone at least four cycles (P4 + P5) compared to only $23.7 \%$ of OTI/NLC T cells, thus corresponding to an increase of $32 \%$. This increase is even more pronounced (53\%) when the immunization was performed with $50 \mu \mathrm{g}$ OVA (15.25\% of OTI/NLC T cells in P4 + P5 compared to $31.87 \%$ of OTI/Daxx-DNT cells) (Figure 7).

We then concluded that antigen-stimulated OTI/Daxx-DNT cells proliferated more than their OTI counterparts, demon- strating that the Daxx-DN transgene affects antigen responsiveness in vivo.

Increased proliferative ability of $\operatorname{Daxx}-D N \mathrm{~T}$ cells is associated with an abnormal signal transduction downstream of the TCR. To study in greater details this increase in T-cell proliferation, we examined some early signalling events elicited upon TCR triggering. The activation status of the MAPK p38, JNK 1/2 and ERK1/2 was followed by analyzing their phosphorylation pattern (Figure 8a). In contrast to NLC T cells, Daxx-DN T cells showed only a moderate p38 MAPK and JNK $1 / 2$ activation after CD3 ligation, whereas ERK1/2 activation under the same conditions appeared to be increased.

Upon TCR engagement, the $\mathrm{NF}_{\kappa} \mathrm{B}$ transcription factors family provides critical integration between signal transduction and transcription pathways activated in $\mathrm{T}$ cells. We therefore analyzed its activation in purified $\mathrm{T}$ cells by gel shift assays upon CD3 activation (Figure 8b). We found a considerable increase of $\mathrm{NF}_{\kappa} \mathrm{B}$ activation in Daxx-DN T cells 
compared to its NLC counterparts in response to anti-CD3 antibody. The same result was found when Jurkat cells were transfected with Daxx shRNA to downregulate endogenous Daxx. Importantly, expression of small interference RNA (siRNA)-escaping silent mutant of $\operatorname{Daxx}(\operatorname{Daxx}-\mathrm{sm})$ efficiently restored a $\mathrm{NF}_{\kappa} \mathrm{B}$ signal (Figure $8 \mathrm{~b}$ ).
We finally assessed the effect of Daxx-DN expression on TCR/CD3 signalling events by determining the levels of TCR/ CD3-induced tyrosine phosphorylation activation of ZAP70 and LAT, two major components of early TCR signalling. An increase in tyrosine phosphorylation of both Zap70 and LAT were observed in Daxx-DN T cells stimulated by anti-CD3 a

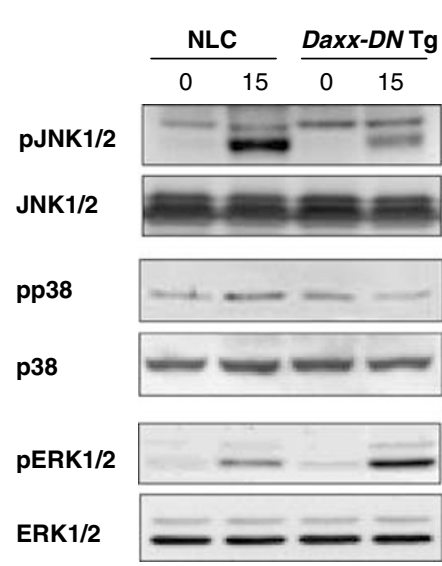

b

T cells

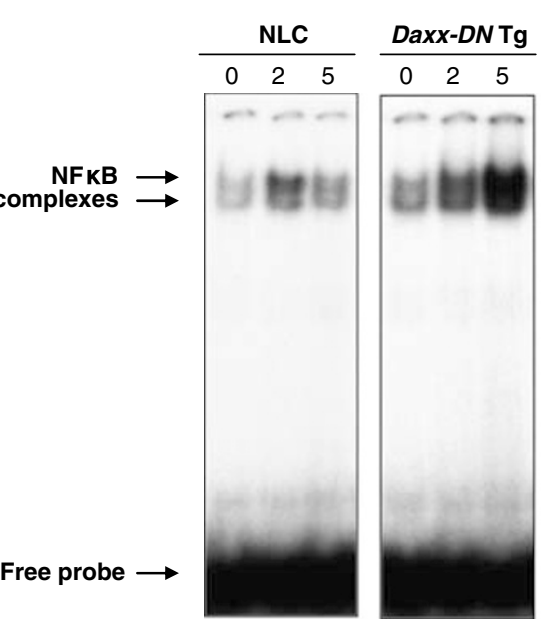

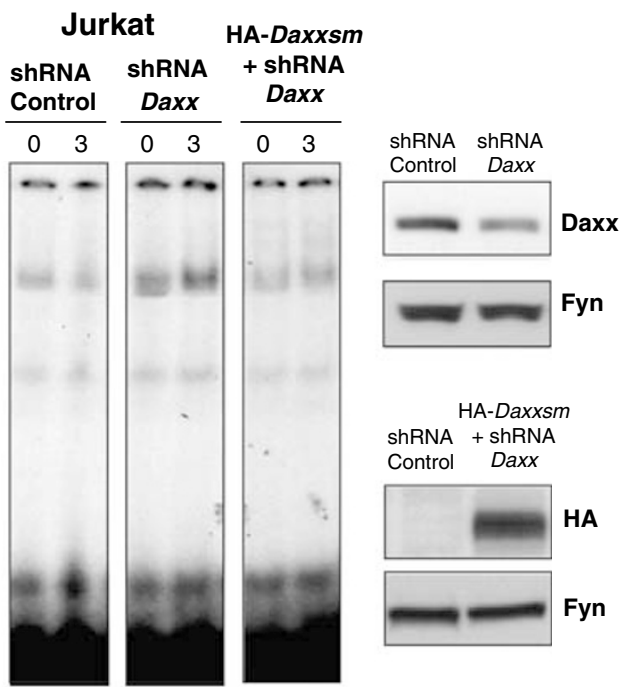

C

T cells

$\frac{N L C}{0 \quad 2} \frac{\operatorname{Daxx}-D N \text { T }}{0 \quad 2}$
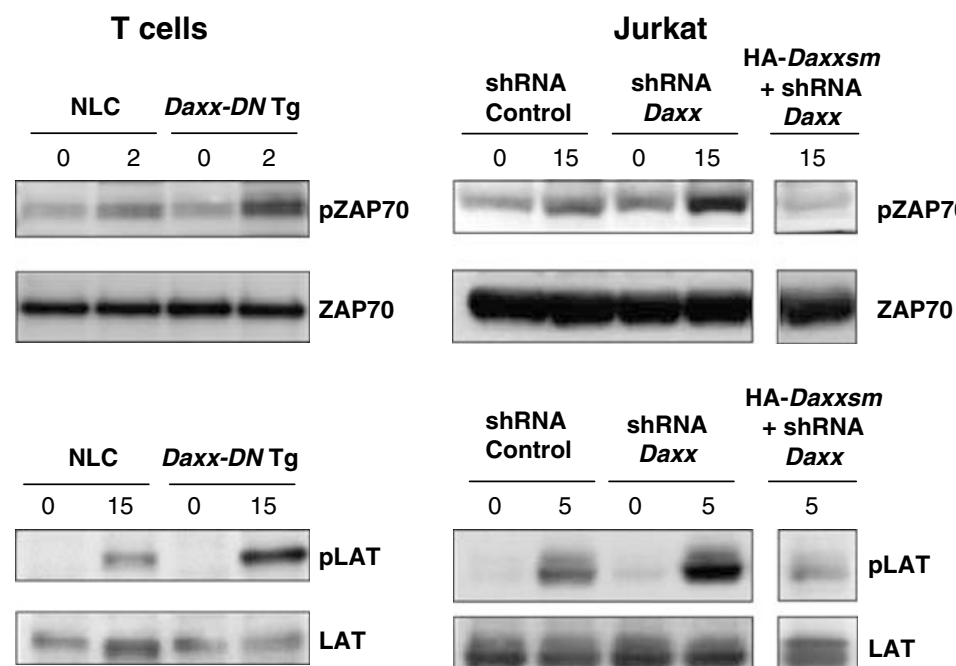

pZAP70

d

IP
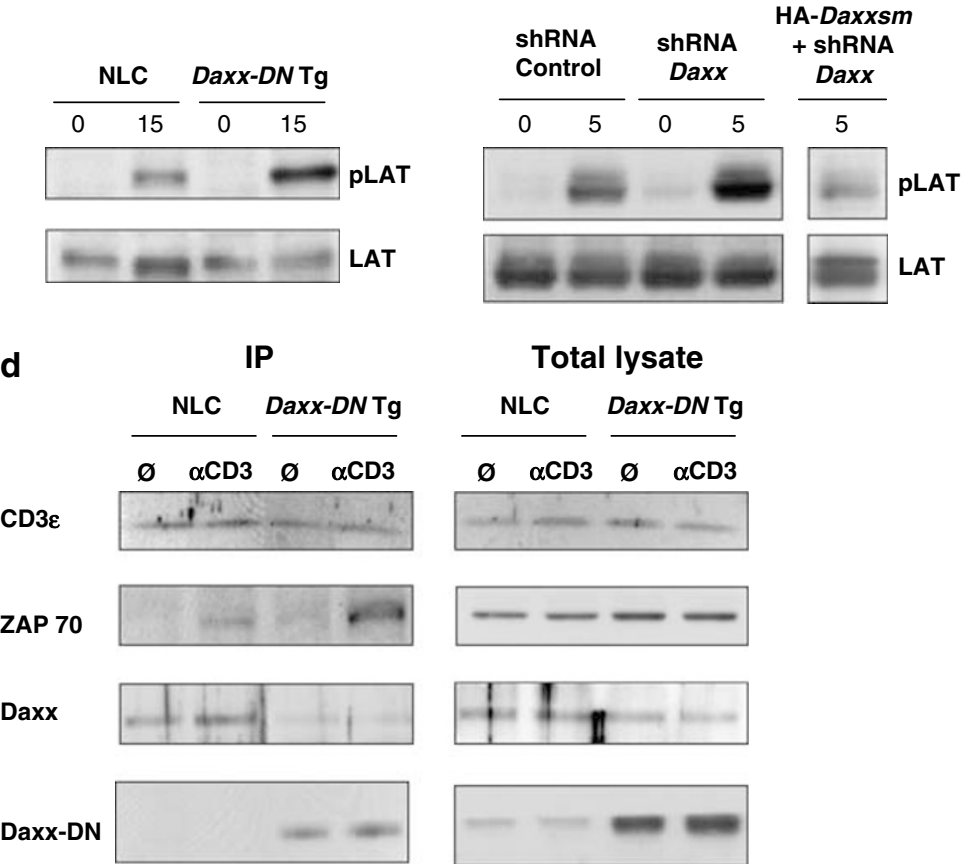

Total lysate
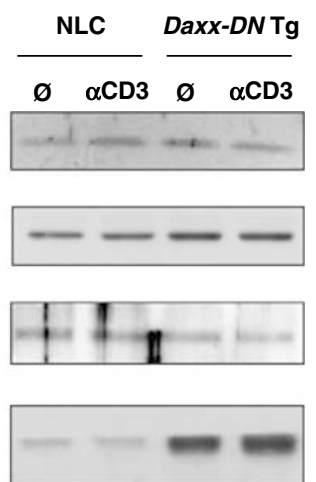
antibody (Figure 8c). Similar to what we carried out for $\mathrm{NF}_{\kappa} \mathrm{B}$ activation, we investigated whether this result could be confirmed in absence of Daxx. The Daxx shRNA transfected Jurkat cells present a higher status of phosphorylation for both ZAP70 and LAT, an effect completely Daxx dependant as the expression of Daxx-sm was enough to inhibit the increase of phosphorylation. This result led us to hypothesize that the effect of the Daxx-DN on TCR-induced proliferation lies very close to the TCR. We show by immunoprecipitation an association of Daxx with TCR both in peripheral $\mathrm{T}$ cells (Figure 8d) and in Jurkat (data not shown) upon CD3 stimulation. This recruitment is in total accordance with the redistribution of Daxx from the nucleus to the cytoplasm upon CD3 stimulation (Supplementary Figure 2).

Interestingly, similar to what we observed for the Fas protein (Figure $3 b$ ), the recruitment of Daxx to the TCR is decreased in the Daxx-DN T cells, whereas both the Daxx-DN and the phosphorylated ZAP70 proteins showed increased levels of TCR association (Figure 8d) suggesting that following CD3 stimulation this truncated form of Daxx promoted the association of ZAP70 to the TCR membrane complex and thereby its phosphorylation.

\section{Discussion}

The importance of Daxx signalling in Fas-mediated cell death and peripheral T-cell deletion. The amount of peripheral $\mathrm{T}$ lymphocytes is strictly controlled through a delicate balance between the generation of $T$ cells that emigrate from the thymus and the elimination of activated lymphocytes. We did not find any difference in the number or distribution of peripheral T-cell subpopulations in Daxx-DN $\mathrm{Tg}$ mice compared with NLC mice suggesting that Daxx is dispensable for T-cell homeostasis. However, we observed in anti-CD3-activated T cells a protection from Fas-mediated cell death provided by the overexpression of Daxx-DN, demonstrating the importance of Daxx in Fas-mediated cell death in this context. Whereas the presence of Fas was shown to be critical in the AICD of proliferating mature T cells in vitro, ${ }^{26-28}$ the death of $\mathrm{T}$ cells activated in vivo was reported to be independent of the Fas/FasL system and, rather, required the presence of proapoptotic members of the $\mathrm{Bcl} 2$ family, for example, Bim, Bax or Bak. ${ }^{29,30}$ In this context, the data reported herein demonstrating that expression of Daxx-DN in T cells has no effect on in vivo AICD, is not really surprising. Similar effect has been described for both FLIP and FADD-DN overexpression ${ }^{16,18}$ and for caspase 8 deficiency. ${ }^{17}$ In concert with the AICD results and, as found for all the above-mentioned genetically modified mice, Daxx-DN Tg mice do not accumulate aberrant $T$ cells nor do the mice succumb to autoimmune diseases. These observations are consistent with the observation that Fas inactivation in $T$ cells alone is insufficient for the pathogenesis of lymphoproliferative disease and that the development of such a syndrome requires the inactivation of Fas in both lymphoid and non-lymphoid tissues. ${ }^{31}$

Upon FasL binding, Daxx is recruited to the DISC and promotes its formation. Although evidences for Daxx involvement in promoting Fas-mediated cell death appear clear from several studies, ${ }^{11}$ Daxx was also reported dispensable for Fas-mediated cell death. ${ }^{10}$ Additionally, antiapoptotic functions for Daxx were also reported for both Fas $^{32}$ and other cell death stimuli and contexts. ${ }^{12,20,33,34}$ More controversial issues were even raised when the binding of Daxx to Fas initially described failed to be reproduced and that the role of Daxx in Fas-mediated cell death was proposed to be initiated from the PML nuclear bodies. ${ }^{5}$ We reported here in primary peripheral $T$ cells that the endogenous Daxx protein is found within the DISC upon Fas stimulation. This recruitment is prevented by the overexpression of Daxx-DN, which decreases the ability of FADD and caspase 8 to be recruited to Fas. We then concluded that at least in T cells, Daxx possesses a critical role in Fas-mediated cell death to optimally form the DISC.

The effect of the absence of Daxx on T-cell proliferation and activation. Signalling molecules of the death receptor pathways, for example, FADD, c-FLIP or caspase 8, play also a critical role in the control of T-cell proliferation. ${ }^{35}$ In this study, we have uncovered a novel role of Daxx in $\mathrm{T}$ lymphocyte activation and proliferation. Daxx-DN expression results in an increased TCR-induced proliferation in T cells, accompanied by an abnormal signal transduction downstream of the TCR. In contrast to Daxx, the three main DISC components containing DED (FADD, caspase 8 and C-FLIP) are required to maintain homeostasis of peripheral $T$ cells as positive regulators of T-cell proliferation. ${ }^{36}$ No real mechanistic links have been yet defined to explain the role of these DED proteins in TCRinduced cell proliferation. Here, we show that the absence of Daxx substantially increases tyrosine phosphorylation of ZAP70 and LAT in response to activation through the TCR. Upon CD3 stimulation, the endogenous Daxx protein is

Figure 8 Early activation pathways in Daxx-DN Tg mice. (a) Phosphorylation of p38, JNKs and Erk1/2 MAPKs expressions following anti-CD3 activation of purified NLC and Daxx-DN T cells. Western blot analysis of protein extracts from purified NLC and Daxx-DN T cells after stimulation for the indicated time with anti-CD3 antibody. Results shown are representative of at least three independent experiments. (b) Daxx deficiency leads to an increase of TCR-induced NF $k B$ activation. T cells from NLC or Daxx-DN Tg mice or Jurkat cells transfected with control shRNAi or Daxx shRNAi alone or with Daxx silent mutation (HA-Daxx sm) were stimulated with anti-CD3 antibody for 0,2 or $5 \mathrm{~h}$ ( $\mathrm{T}$ cells) or for $3 \mathrm{~h}$ (Jurkat cells). Nuclear extracts were prepared, and gel mobility shift assays were performed using ${ }^{32} \mathrm{P}$-labelled probes containing $\mathrm{NF} \kappa \mathrm{B}$ binding sites. Arrowheads indicate the $\mathrm{NF} \kappa \mathrm{B}$ complexes or the free ${ }^{32} \mathrm{P}$ labelled probes. Western blot analysis of total lysates from the Jurkat cells shows the decrease of endogenous Daxx protein expression upon shRNA and the expression of the overexpressed HA-Daxx sm. (c) Increased phosphorylation of LAT and ZAP70 upon TCR triggering in both DaxxDN T cells and in Daxx shRNA expressing Jurkat cells. Cells were left unstimulated or stimulated with anti-CD3 for the indicated time (min). Following receptor cross-linking, total cell lysates were prepared and examined by immunoblotting with specific phospho-LAT or phospho-ZAP70 antibodies. Total lysates were also immunoblotted with total ZAP70 and LAT antibodies to demonstrate that the higher phosphorylation of theses proteins was not due to their increased protein levels. (d) Association of Daxx with TCR upon CD3 stimulation. Anti-TCR chain immunoprecipitates from NLC or Daxx-DN Tg T cells (activated or not during the indicated time (min) with $20 \mu \mathrm{g}$ of anti-CD3) were immunoblotted with the indicated antibodies (anti-FLAG antibody was used to detected Daxx-DN) 
rapidly recruited to the TCR and this recruitment is prevented by the overexpression of the Daxx-DN, which favors the association of ZAP70 to the TCR membrane complex and thereby its phosphorylation (Figure 8d). We therefore propose that Daxx, by binding to the TCR complex upon CD3 stimulation (Figure 8d) might limit the tyrosine phosphorylation of both LAT and ZAP70, two initial events in TCR activation cascade, and rather plays a role in TCR signalling pathways than in a cell cycle pathway.

Of note is that whereas the action of Daxx lies very close to the TCR activation at the membrane, the three others DED proteins belonging to the DISC, FADD, caspase 8 and FLIP, may collaborate further downstream of the TCR triggering probably by interacting with the CARMA complex. ${ }^{37}$

Interestingly, although we cannot completely exclude an additional role for Daxx in transcriptional regulation, we demonstrate here that Daxx can also exert some of its functions by directly interacting with some receptors, independently of its role in transcriptional regulation and/or p53 activation/stability, as described in others contexts. ${ }^{12,13}$

Finally, it is likely that the role of Daxx in the regulation of cell proliferation is restricted neither to the T-cell compartment nor to the TCR-induced proliferation as: (i) a functional link of Daxx with a growth inhibitory effect has been recently reported upon CD40-mediated B-cell activation in vivo ${ }^{38}$ as Daxxoverexpressing $B$ lymphocytes stimulated with anti-CD40 antibodies proliferate less than their wild-type counterparts, thus revealing also a growth-suppressive function of Daxx in the B compartment and (ii) Daxx is found associated to TGF- $\beta$ receptor $\mathrm{II}^{39}$ a receptor whose role in T-cell proliferation is critical in maintaining $\mathrm{T}$-cell homeostasis and preventing lymphoproliferative disorder. ${ }^{40}$

In conclusion, our results not only confirmed the essential proapoptotic role of Daxx in Fas-mediated cell death in vivo but also revealed a role of this protein in the regulation of TCRinduced proliferation of $T$ cells by interfering in the very early proximal TCR pathway.

\footnotetext{
Materials and Methods

Antibodies and reagents. The antibodies used were: anti-CD4 (RM4-S), anti-CD8 (53-6.7), anti-V $\beta 8$ (F23.1), anti-V $\beta 3$ (KJ25), anti-V $\beta 6$ (RR4-7), anti-V $\alpha 2$ (B20.1), anti-FLAG (M2) from Sigma; anti-FADD from Calbiochem; anti-Fas (M20), anti-Daxx (M112), anti-Fyn, anti-Cyclin A, anti-Cyclin E, anti-Cdk2, anti-Cdk4, antiCdk6, anti-p15, anti-p16, anti-p19, anti-p21, anti-p27, anti-Cdc25, anti-Rab5, anti IKB- $\alpha$, anti-p53, anti-phospho JNK (G-7) from Santa Cruz; anti-caspase 3 and biotin-conjugated anti-Fas (JO2) from Pharmingen; anti-caspase 9 (5B4) from MBL; anti-Daxx (Daxx01) and anti-caspase 8 (1G12) from Alexis; anti-p38, anti-phospho p38, anti-ERK1/2, anti-phospho ZAP70 (Tyr319), anti-phospho LAT (Tyr191) from Cell Signalling; anti-Cyclin D1 (DCS-6), anti-Cyclin D3 (DCS-28.1) from Neomarkers; anti-LAT (Upstate), anti-ZAP70 from Transduction Laboratories; anti-HA (16B12) from Covance; horseradish peroxidase-conjugated anti-rabbit or anti-mouse antibodies from Jackson ImmunoResearch. Recombinant human FasL, Z-Vad were from Alexis Corporation; Streptavidin-agarose beads from SigmaAldrich; Protein A/G plus-agarose beads from Santa Cruz; staurosporine, PMA (phorbol myristate acetate) and ionomycin from Sigma; Protein A from AmershamPharmacia Biotech; and recombinant mouse interleukin-2 (IL-2) from Roche Biochemicals. Anti-CD3e (145.2c11) used in mouse T-cell proliferation assay and for immunoprecipitation was purified from hybridoma supernatant. Anti-human $\mathrm{CD} 3 \varepsilon$ (UCHT-1) was from Pharmingen.
}

Generation of Ick-Daxx-DN Tg mice. The FLAG-Daxx-DN fragment (prepared as described Raoul et al..$^{19}$ ) was ligated into the blunted p1017 Ick proximal promoter murine expression vector. The purified Notl fragment containing the murine Ick promoter-FLAG/Daxx-DN transgene was injected into the male pronucleus of fertilized C57BL/6 animals. Resulting embryos were transferred into day 1-plugged pseudo-pregnant foster mice. Transgenic founders were identified by Southern blot analysis of DNA derived from tail snips. Heterozygous founder mice were backcrossed to C57BL/6 mice. Transgenic lines had no overt phenotype by observation and were maintained at heterozygosity and compared with NLC. The Ick-FADD-DN mice were described previously. ${ }^{24}$

To study AICD in vivo and antigen-induced proliferation in vivo, Daxx-DN Tg mice were crossed with Balb/c and OT-1 mice,$^{25}$ respectively.

siRNA and construction of expression vectors. The gene-specific insert, containing sequences corresponding to nucleotides 2054-2072 (gtggactctcccagccatg) of human Daxx and its reverse complement, which were separated from each other by a nine-nucleotide non-complementary spacer (ttcaagaga), was cloned into the mammalian expression vectors pSuper (OligoEngine) or pTer. This vector was referred to as Daxx shRNAi. In order to reintroduce the expression of Daxx in the cells whose expression of Daxx had been suppressed by siRNA, we transfected the cells with pCDNA3.1 HA-mouse Daxx plasmids to which we introduced two silent mutations (Daxx-sm) within the sequence corresponding to the Daxx siRNA via site-directed mutagenesis (QuickChange, Stratagene) using the following primers: $5^{\prime}$-GTG GAC TCA CCC AGT CAT GAA- $3^{\prime}$ and $5^{\prime}$-TTC ATG ACT GGG TGA GTC CAC- $3^{\prime}$. The silent mutations allowed the expression of the reintroduced Daxx-sm, whereas the expression of the endogenous Daxx was suppressed as a result of the Daxx siRNA.

Peripheral T-cell isolation and purification. T-lymphocyte suspensions were prepared from spleen and inguinal lymph nodes from 6- to 10-week-old mice. Mature $T$ cells were isolated from splenocytes using a mouse T-cell negative isolation kit according to the supplier's protocol (Dynal Biotech SA).

L12. 10 and Jurkat cell transfection. Jurkat cells were transiently transfected using the Amaxa Nucleofection technology ${ }^{\mathrm{TM}}$ (Amaxa, Koeln, Germany). Cells were resuspended in solution from Nucleofector kit V (Program S18) following the manufacturer's protocol for cell line transfection.

L12.10.mFas cells expressing short hairpin Daxx siRNA or control siRNA were established by stably transfecting cells with mouse Daxx shRNAi (shRNA Daxx) or control shRNAi (shRNA control) and selected for stable cells with Zeocin.

Flow cytometry analysis (extracellular or intracellular staining). Cells $\left(0.5-1 \times 10^{6}\right)$ were incubated with saturating amounts of conjugated antibodies for $30 \mathrm{~min}$ at $4^{\circ} \mathrm{C}$ in PBS, 1\% BSA (buffer F). After two washes in buffer $F$, streptavidin tri-color (Caltag) was added in the samples containing biotinylated antibodies. After $30 \mathrm{~min}$ incubation at $4^{\circ} \mathrm{C}$, cells were washed twice and analyzed. FLAG-tagged Daxx-DN expression was determined by cytoplasmic immunofluorescence staining. Cells were fixed for $15 \mathrm{~min}$ at room temperature in PBS, $1 \%$ paraformaldehyde and stained for $30 \mathrm{~min}$ on ice with $0.5 \mu \mathrm{g} / \mathrm{ml}$ mouse anti-FLAG (M5) monoclonal antibody in the presence of $1 \% \mathrm{BSA}$ and $0.3 \%$ saponin (Sigma). Alexa Fluor-488-conjugated goat anti-mouse IgG (Fab'2-fragment) antibody (Molecular probes, Eugene, Oregon, USA) was used at $10 \mu \mathrm{g} / \mathrm{ml}$ as secondary reagent. Purified splenic T cells were stained with CFSE (Molecular Probes, Eugene, Oregon, USA) as described. ${ }^{24}$

Staphylococcus enterotoxin-B-mediated T-cell deletion. Six- to 10-week-old NLC and Daxx-DN Tg mice were i.v.-injected with $100 \mu \mathrm{g} \mathrm{SEB}$ $(1 \mathrm{mg} / \mathrm{ml}$ in PBS; Sigma Chemical Co., St Louis, MO, USA) and killed 3 or 8 days later to measure the amount of $\mathrm{V} \beta 8^{+}$and $\mathrm{V} \beta 6^{+} \mathrm{T}$-cell expansion. Spleen and lymph node single cell suspensions were prepared and stained for cytometry analysis with anti-mV $\beta 8$-FITC/anti-CD8-biot (Caltag) or anti-mV $\beta 8$-FITC/antiCD4-PE antibodies to detect T-cell expansion. As V $\beta 6$ is not deleted by SEB, anti-mV $\beta 6$-FITC instead of anti-mV $\beta 8$-FITC antibody was used as a control.

Fas and TCR activation procedures; Western blot analyses. For Fas activation, cells were collected, pre-warmed $4 \mathrm{~min}$ at $37^{\circ} \mathrm{C}$ and stimulated with FLAG-rhFasL $(0.1 \mu \mathrm{g} / \mathrm{ml}$ for T-cells and $0.025 \mu \mathrm{g} / \mathrm{ml}$ for L12.10) plus $1 \mu \mathrm{g} / \mathrm{ml}$ antiFLAG antibody at $37^{\circ} \mathrm{C}$. For $\mathrm{CD} 3$ activation, cells were first pre-incubated at $37^{\circ} \mathrm{C}$ for $5 \mathrm{~min}$ and then activated with anti-CD3 antibody (UCHT1, $20 \mu \mathrm{g} / \mathrm{ml}$ for T cells and $5 \mu \mathrm{g} / \mathrm{ml}$ for Jurkat). 
DISC isolation and TCR immunoprecipitation. DISC isolation was performed on T cells $\left(5 \times 10^{7}\right)$ or on L12.10 cells $\left(10 \times 10^{7}\right)$ stimulated with $200 \mathrm{ng} / \mathrm{ml}$ (T cells) or $100 \mathrm{ng} / \mathrm{ml}$ (L12.10) FLAG-rhFasL plus $2 \mu \mathrm{g} / \mathrm{ml}$ M2 antibody for $5 \mathrm{~min}$ or left unstimulated at $37^{\circ} \mathrm{C}$. The post-nuclear supernatant (PNS) was prepared and solubilized in buffer A containing $0.5 \%$ Nonidet-P40 and $10 \%$ glycerol (lysis buffer) at $4{ }^{\circ} \mathrm{C}$ and then subjected to immunoprecipitation with biotinylated $\mathrm{JO} 2$ anti-Fas antibody coupled to streptavidin-agarose beads at $4^{\circ} \mathrm{C}$, overnight. The beads were washed four times with lysis buffer and the immunoprecipitates were eluted from beads by heating in Laemmli buffer at $95^{\circ} \mathrm{C}$ for $5 \mathrm{~min}$ and subjected to SDS-PAGE, followed by immunoblotting with indicated antibodies.

TCR complex isolation was performed on T cells $\left(2 \times 10^{7}\right)$ stimulated with $20 \mu \mathrm{g} / \mathrm{ml}$ anti-CD3 $\varepsilon$ antibody $(145.2 \mathrm{c} 11)$ for $3 \mathrm{~min}$ or left unstimulated at $37^{\circ} \mathrm{C}$. The PNS was prepared and solubilized in buffer A containing $0.5 \%$ Nonidet-P40 and $10 \%$ glycerol (lysis buffer) at $4{ }^{\circ} \mathrm{C}$ and then subjected to immunoprecipitation with Protein A/G plus-agarose beads at $4^{\circ} \mathrm{C}$, overnight. Anti-CD3 $\varepsilon$ antibody (145.2c11) was added to the unstimulated samples $(1 \mu \mathrm{g} / \mathrm{ml})$. The beads were washed four times with lysis buffer and the immunoprecipitates were eluted from beads by heating in Laemmli buffer at $95^{\circ} \mathrm{C}$ for $5 \mathrm{~min}$ and subjected to SDS-PAGE, followed by immunoblotting with indicated antibodies.

Cell death experiments. Cell death experiments on purified T cells were performed after CD3 activation: briefly, cells $\left(2 \times 10^{6}\right.$ cells/well, 24-well plate) were stimulated with plate-bound anti-CD3 antibody $(1 \mu \mathrm{g} / \mathrm{ml})$, in the presence of recombinant mouse IL-2 $(50 \mathrm{U} / \mathrm{ml})$ for 4 days. The cells were then collected and either plated at $10^{6} \mathrm{cell} / \mathrm{s} / \mathrm{ml}$ for $4 \mathrm{~h}$ for killing assay with FLAG-rhFasL/anti-FLAG antibody or with staurosporine, or for in vitro AICD, washed, put back into culture in the presence of $\mathrm{IL}-2(50 \mathrm{U} / \mathrm{ml})$ for 2 more days, before being restimulated with platebound CD3 MAb $(1 \mu \mathrm{g} / \mathrm{ml})$ for $24 \mathrm{~h}$.

L12.10 cells were washed twice with serum-free medium, distributed at $1 \times 10^{6} \mathrm{cells} / \mathrm{ml}$ and treated with FLAG-rhFasL/anti-FLAG antibody for $4 \mathrm{~h}$.

Cell death was determined by propidium iodide (PI) staining on fixed cells as described previously. ${ }^{24}$

In vitro proliferation analysis. ${ }^{3}[\mathrm{H}]$ thymidine incorporation assay were performed as described by Zörnig et al. ${ }^{24}$

T-cell adoptive transfer and immunizations. CFSE-labelled purified $T$ cells $\left(6 \times 10^{6}\right.$ cells) from Daxx-DN $\times$ OT-1 mice were transferred through an i.v. injection into congenic recipient mice. Mice were immunized subcutaneously $24 \mathrm{~h}$ post-transfer with 10 or $50 \mu \mathrm{g}$ of OVA (Sigma-Aldrich) emulsified in CFA (SigmaAldrich). Two days post-injection, mice were killed and lymph nodes were removed. Single-cell suspensions were surface-stained with PE-labelled anti-V $\alpha 2$ and biotinlabelled anti-CD8. Proliferation of TCR Tg T cells was determined by the CFSE profile analysis within the $\mathrm{CD} 8^{+} \mathrm{V} \alpha 2^{+} \mathrm{T}$-cell subset.

Electrophoretic mobility shift assay (EMSA). EMSA were performed as described previously. ${ }^{41}$

Acknowledgements. We are especially grateful to Gerard Evan for support and input at the initial phase of this work. Our thanks to the animal units at Imperial Cancer Research Fund/CRUK, to lan Rosewell for assistance with transgene microinjection, Sylvie Guerder for technical advice, Sebastien Huault and Mouna Sekoni for excellent technical assistance. We also thank $D$ Baltimore for his generous gift of the mouse Daxx cDNA and E Berra for advices with the shRNA technique. This work was supported by institutional funds from the Centre National de la Recherche Scientifique (CNRS), and by grants from the Ligue Nationale Centre le Cancer (Equipe Labellisée) Association pour la Recherche contre le Cancer (ARC), the Emerald Foundation, and the Canceropole-PACA ACI 2004. KC is a post-doctoral fellow of Susan G Komen Breast Cancer Foundation.

1. Gaur U, Aggarwal BB. Regulation of proliferation, survival and apoptosis by members of the TNF superfamily. Biochem Pharmacol 2003; 66: 1403-1408.

2. Peter ME, Krammer PH. The CD95 (APO-1/Fas) DISC and beyond. Cell Death Differ 2003; 10: 26-35.

3. Wang X. The expanding role of mitochondria in apoptosis. Genes Dev 2001; 15: 2922 2933.

4. Yang $\mathrm{X}$, Khosravi-Far R, Chang H, Baltimore D. Daxx, a novel Fas-binding protein that activates JNK and apoptosis. Cell 1997; 89: 1067-1076.
5. Torii S, Egan DA, Evans RA, Reed JC. Human Daxx regulates Fas-induced apoptosis from nuclear PML oncogenic domains (PODs). EMBO J 1999; 18: 6037-6049.

6. Chang HY, Yang X, Baltimore D. Dissecting Fas signaling with an altered-specificity death domain mutant: requirement of FADD binding for apoptosis but not Jun $\mathrm{N}$-terminal kinase activation. Proc Natl Acad Sci USA 1999; 96: 1252-1256.

7. Chang HY, Nishitoh $H$, Yang X, Ichijo H, Baltimore D. Activation of apoptosis signalregulating kinase 1 (ASK1) by the adapter protein Daxx. Science 1998; 281: 1860-1863.

8. Ko YG, Kim EY, Kim T, Park H, Park HS, Choi EJ et al. Glutamine-dependent antiapoptotic interaction of human glutaminyl-tRNA synthetase with apoptosis signal-regulating kinase 1. J Biol Chem 2001; 276: 6030-6036.

9. Gostissa M, Morelli M, Mantovani F, Guida E, Piazza S, Collavin L et al. The transcriptional repressor hDaxx potentiates p53-dependent apoptosis. J Biol Chem 2004; 279: 48013-48023.

10. Villunger A, Huang DC, Holler N, Tschopp J, Strasser A. Fas ligand-induced c-Jun kinase activation in lymphoid cells requires extensive receptor aggregation but is independent of DAXX, and Fas-mediated cell death does not involve DAXX, RIP, or RAIDD. J Immunol 2000; 165: 1337-1343.

11. Salomoni P, Khelifi AF. Daxx: death or survival protein? Trends Cell Biol 2006; 16: 97-104.

12. Tang J, Qu LK, Zhang J, Wang W, Michaelson JS, Degenhardt YY et al. Critical role for Daxx in regulating Mdm2. Nat Cell Biol 2006; 8: 855-862.

13. Zhao LY, Liu J, Sidhu GS, Niu Y, Liu Y, Wang R et al. Negative regulation of p53 functions by Daxx and the involvement of MDM2. J Biol Chem 2004; 279: 50566-50579.

14. Krammer PH. CD95's deadly mission in the immune system. Nature 2000; 407: 789-795.

15. Beisner DR, Chu IH, Arechiga AF, Hedrick SM, Walsh CM. The requirements for Fasassociated death domain signaling in mature $\mathrm{T}$ cell activation and survival. $\mathrm{J}$ Immunol 2003; 171: 247-256.

16. Lens SM, Kataoka T, Fortner KA, Tinel A, Ferrero I, MacDonald RH et al. The caspase 8 inhibitor c-FLIP(L) modulates T-cell receptor-induced proliferation but not activationinduced cell death of lymphocytes. Mol Cell Biol 2002; 22: 5419-5433.

17. Salmena L, Lemmers B, Hakem A, Matysiak-Zablocki E, Murakami K, Au PY et al. Essential role for caspase 8 in T-cell homeostasis and T-cell-mediated immunity. Genes Dev 2003; 17: 883-895.

18. Tai TS, Fang LW, Lai MZ. c-FLICE inhibitory protein expression inhibits T-cell activation. Cell Death Differ 2004; 11: 69-79.

19. Raoul C, Barthelemy C, Couzinet A, Hancock D, Pettmann B, Hueber AO. Expression of a dominant negative form of Daxx in vivo rescues motoneurons from Fas (CD95)-induced cell death. J Neurobiol 2005; 62: 178-188.

20. Michaelson JS, Bader D, Kuo F, Kozak C, Leder P. Loss of daxx, a promiscuously interacting protein, results in extensive apoptosis in early mouse development. Genes Dev 1999; 13: 1918-1923

21. Peter ME, Kischkel FC, Scheuerpflug CG, Medema JP, Debatin KM, Krammer PH. Resistance of cultured peripheral T cells towards activation-induced cell death involves a lack of recruitment of FLICE (MACH/caspase 8) to the CD95 death-inducing signaling complex. Eur J Immunol 1997; 27: 1207-1212.

22. Newton K, Harris AW, Bath ML, Smith KG, Strasser A. A dominant interfering mutant of FADD/MORT1 enhances deletion of autoreactive thymocytes and inhibits proliferation of mature T lymphocytes. EMBO J 1998; 17: 706-718.

23. Walsh CM, Wen BG, Chinnaiyan AM, O'Rourke K, Dixit VM, Hedrick SM. A role for FADD in T cell activation and development. Immunity 1998; 8: 439-449.

24. Zörnig M, Hueber AO, Evan G. p53-dependent impairment of T-cell proliferation in FADD dominant-negative transgenic mice. Curr Biol 1998; 8: 467-470.

25. Hogquist KA, Jameson SC, Heath WR, Howard JL, Bevan MJ, Carbone FR. T cell receptor antagonist peptides induce positive selection. Cell 1994; 76: 17-27.

26. Alderson MR, Tough TW, Davis-Smith T, Braddy S, Falk B, Schooley KA et al. Fas ligand mediates activation-induced cell death in human T lymphocytes. J Exp Med 1995; 181: $71-77$.

27. Dhein J, Walczak H, Baumler C, Debatin KM, Krammer PH. Autocrine T-cell suicide mediated by APO-1/(Fas/CD95). Nature 1995; 373: 438-441.

28. Ju ST, Panka DJ, Cui H, Ettinger R, el-Khatib M, Sherr DH et al. Fas(CD95)/FasL interactions required for programmed cell death after T-cell activation. Nature 1995; 373: 444-448.

29. Hildeman DA, Zhu Y, Mitchell TC, Bouillet P, Strasser A, Kappler J et al. Activated T cell death in vivo mediated by proapoptotic bcl-2 family member bim. Immunity 2002; 16 : 759-767.

30. Rathmell JC, Lindsten T, Zong WX, Cinalli RM, Thompson CB. Deficiency in Bak and Bax perturbs thymic selection and lymphoid homeostasis. Nat Immunol 2002; 3: 932-939.

31. Hao Z, Hampel B, Yagita H, Rajewsky K. T cell-specific ablation of Fas leads to Fas ligandmediated lymphocyte depletion and inflammatory pulmonary fibrosis. J Exp Med 2004; 199: $1355-1365$

32. Chen LY, Chen JD. Daxx silencing sensitizes cells to multiple apoptotic pathways. Mol Cell Biol 2003; 23: 7108-7121.

33. Michaelson JS, Leder P. RNAi reveals anti-apoptotic and transcriptionally repressive activities of DAXX. J Cell Sci 2003; 116: 345-352.

34. Cermak L, Simova S, Pintzas A, Horejsi V, Andera L. Molecular mechanisms involved in CD43-mediated apoptosis of TF-1 cells. Roles of transcription Daxx expression, and adhesion molecules. J Biol Chem 2002; 277: 7955-7961. 
35. Wajant $\mathrm{H}$, Pfizenmaier $\mathrm{K}$, Scheurich $\mathrm{P}$. Non-apoptotic Fas signaling. Cytokine Growth Factor Rev 2003; 14: 53-66.

36. Budd RC, Yeh WC, Tschopp J. cFLIP regulation of lymphocyte activation and development. Nat Rev Immunol 2006; 6: 196-204.

37. Thome M, Tschopp J. TCR-induced NF-kappaB activation: a crucial role for Carma1, Bcl10 and MALT1. Trends Immunol 2003; 24: 419-424.

38. Salomoni P, Guernah I, Pandolfi PP. The PML-nuclear body associated protein Daxx regulates the cellular response to CD40. Cell Death Differ 2006; 13: 672-675.
39. Perlman R, Schiemann WP, Brooks MW, Lodish HF, Weinberg RA. TGF-beta-induced apoptosis is mediated by the adapter protein Daxx that facilitates JNK activation. Nat Cell Biol 2001; 3: 708-714.

40. Li MO, Wan YY, Sanjabi S, Robertson AK, Flavell RA. Transforming growth factor-beta regulation of immune responses. Annu Rev Immunol 2006; 24: 99-146.

41. Van Lint C, Ghysdael J, Paras Jr P, Burny A, Verdin E. A transcriptional regulatory element is associated with a nuclease-hypersensitive site in the pol gene of human immunodeficiency virus type 1. J Virol 1994; 68: 2632-2648.

Supplementary Information accompanies the paper on Cell Death and Differentiation website (http://www.nature.com/cdd) 